\title{
Enzymatic and histopathologic biomarkers as indicators of aquatic pollution in fishes
}

\author{
Alaa G. M. Osman ${ }^{1 *}$, Abd-El-Baset M. Abd El Reheem ${ }^{1}$, Khalid Y. AbuelFadI ${ }^{2}$, \\ Ali G. GadEI-Rab ${ }^{1}$ \\ ${ }^{1}$ Department of Zoology, Faculty of Science, Al-Azhar University (Assiut Branch), Assiut, Egypt; *Corresponding author: os- \\ man@igb-berlin.de \\ ${ }^{2}$ The Egyptian Environmental Affairs Agency (EEAA), Assiut, Egypt
}

Received 6 August 2010; revised 20 September 2010; accepted 25 September 2010.

\begin{abstract}
In the present study we investigated the alteration in the activity of two metabolic enzymes [Glucose-6-Phosphate Dehydrogenase (G6PDH) and Lactate Dehydrogenase (LDH)] and the histological changes on liver and gills of the African catfish Clarias gariepinus collected from 6 sites along the river Nile, from its spring at Aswan to its estuary at Rosetta and Damietta branches. The results showed that the physical and chemical parameters of the water collected from Damietta and Rosetta branches were higher than those of the water collected from other sites. Remarkable alterations in the activity of the selected enzymes in the liver and muscles of the African catfish were detected. These alterations go in parallel with the elevation in the levels of chemical parameters detected in the water of Damietta and Rosetta branches as a result of pollution stress in these areas. The activity of G6PDH was significantly ( $p<0.05$ ) decreased from Aswan to Rosetta and Damietta recording the highest value at Rosetta followed by Damietta water. The activity of LDH showed a significant elevation $(p<0.05)$ in activity in the liver and muscles of fishes collected from Rosetta and Damietta branches comparing to other sites. These alterations in enzymatic activities were followed, in the present study, by the occurrence of histological lesions and clear damage in liver and gill tissues of the African catfish collected from the same sites. Thus we may conclude that, the altered activities of G6PDH and LDH could be useful biomarkers of water pollution. At the same time, histopathology provides a reliable, easily quantifiable index of low-level toxic stress to a broad range of environmental pollutants.
\end{abstract}

Keywords: Metabolic enzyme; Histopathology; Biomarker; aquatic pollution; Rive Nile; African catfish

\section{INTRODUCTION}

Contamination of fresh water with a wide range of pollutants has become a matter of concern over the last few decades [1,2]. Water pollution is one of the principal environmental and public health problems that Egyptian River Nile are facing [3]. The Nile represents the main freshwater resource for the country, meeting nearly all demands for drinking water, irrigation, and industry. During its transit through Egypt, the river Nile receives numerous non-point and point source discharges[4]. Even with the presence of numerous studies on aquatic pollution [5-17] information about the biological effects of pollution on the aquatic organism is lacking and show many gaps. Fish have been the most popular choice as test organism and for monitoring aquatic toxicity because they are presumably the best-understood organisms in the aquatic environment, their large mobility allows them to assess large -scale regional affect, and also due to their importance to man as a protein source $[18,19]$.

Biochemical and physiological indicators such as enzymes, could be used (as biomarkers) to identify possible environmental contaminations before the health of aquatic organisms is seriously affected [20,21] and to develop water quality indices [22-26]. Such a biochemical approach has been advocated to provide an early warning of potentially damaging changes in stressed fish [27]. In toxicological studies of acute exposure, changes in concentrations and activities of some enzymes may reflect cell damage in specific organs [27,28]. Glucose-6-Phosphate dehydrogenase (G6PDH) has long been recognized as an antioxidant enzyme [29-31] and is 
relevant as a marker for carcinogenesis in mammals and also as a biomarker of pollution-induced carcinogenesis in fish. The cytoplasmic enzyme lactate dehydrogenase (LDH) is widely used as marker of organ or tissue lesions in toxicology and in clinical chemistry [32-34]. This enzyme commonly reflects the metabolic capacity of a tissue. G6PDH and LDH are key factors in the metabolism with high sensitivity to pollutants [25,35-38].

Altered morphology, or altered structure, is the expression of the disease process that is examined by the pathologist. Histopathology is the microscopic evaluation of these disease processes $[36,39,40]$. It is a very powerful, subjective tool which may be used to establish primary and secondary disease patterns in populations of fish. Most biomarkers are narrow in their expression whereas pathology is broad in its evaluation [41]. There is a dearth of literature concerning the critical evaluation of fish histopathology in environmental effects monitoring.

The present paper is a part of a detailed investigation entitled (Biomonitoring of the river Nile pollution using biomarker responses in fishes). The present part aimed to study the alteration of the selected metabolic enzymes (G6PDH and LDH) and the histological changes on the liver and gills of the African catfish (Clarias gariepinus) as biomarkers in combination with chemical analysis of the water from six different sites along the whole course of the river Nile from its spring at Aswan to its estuaries at Rosetta and Damietta.

\section{MATERIALS AND METHODS}

\subsection{Study Area}

The program of monitoring had been planned and implemented to evaluate the quality of water and the influence of the drained water on the aquatic biota. Eighteen different sampling points from six sites (three points for each site) were selected along the whole course of the river Nile from its spring at Aswan to its estuaries at Rosetta and Damietta (Figure 1).

\begin{tabular}{ll}
\hline Sites & Corresponding points \\
\hline Aswan & Aswan city, Aswan dam, and Kom-Umbo. \\
Qena & Armant, Qena, and Naj-Hamadi. \\
Assiut & Sedfa, Assiut, and Qusia. \\
Beni-Suef & Al-Fashen, Beni-Suef, and Al-Wasta. \\
Damietta & Zefta, Mansoura, and Damitta. \\
Rosetta & Cairo, Kafr-Elzeyat, and Rasheed. \\
\hline
\end{tabular}

\subsection{Water Analysis}

Four water samples were collected using polyvinyl chloride Van Dorn bottle (5 L capacity) at two meters depth from the selected points along the main course of

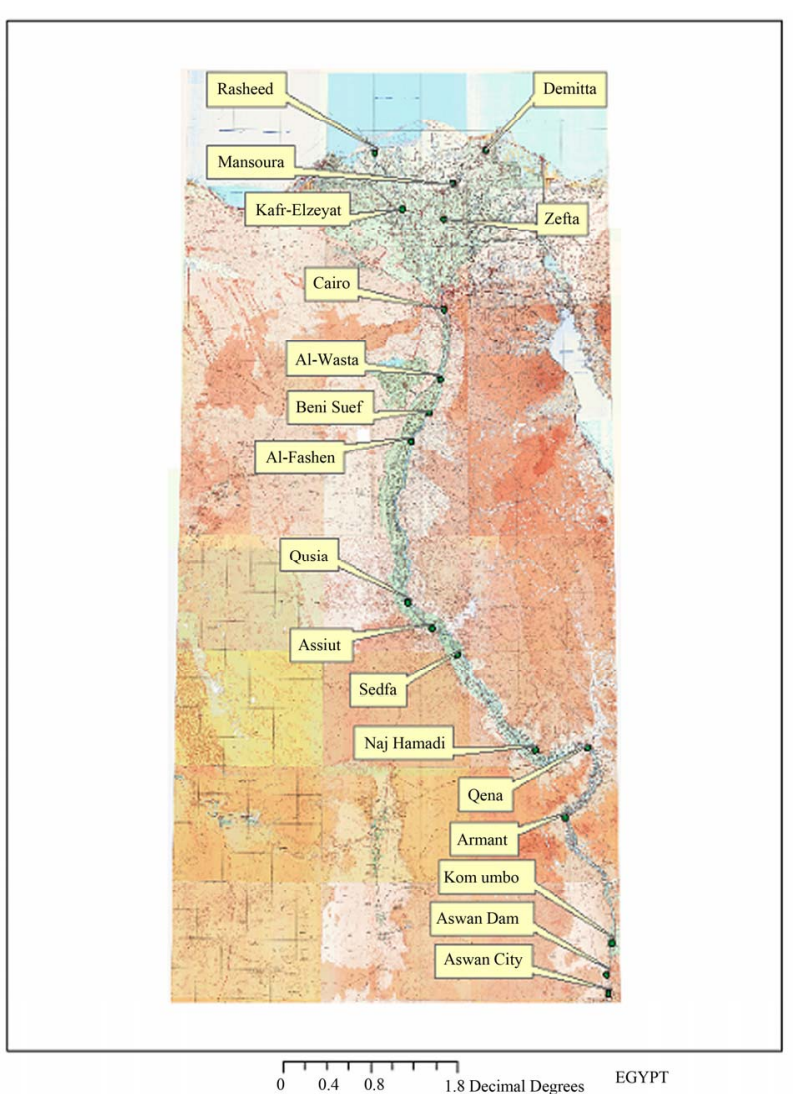

Figure 1. Map showing the sampling sites along the whole course of the river Nile from its spring at Aswan to its estuary at Damietta and Rosetta branch.

the river Nile. Water samples were kept in a one-litre polyethylene bottle in ice box and analyzed in the laboratory. Some of the physicochemical parameters including the electrical conductivity of the water samples $(\mathrm{mScm}-1), \mathrm{pH}$, water temperature $\left({ }^{\circ} \mathrm{C}\right)$ and Turbidity (NTU) were measured by using water checker U-10 Horiba Ltd. The other water criteria [Chemical oxygen demand (COD), Total Organic Compound (TOC), Total solids (TS), ammonia (NH3), Nitrate (NO3) Orthophosphate (O-PO4) Chloride (CL) Florid (F) Sulfate (SO4), Phenolics (Phenol)] were measured according to the traditional manual methods [42].

Total $\mathrm{Pb}, \mathrm{Cu}, \mathrm{Cr}, \mathrm{Mn}, \mathrm{Zn}, \mathrm{Hg}, \mathrm{Fe}, \mathrm{Cd}$ were measured after digestion using Graphite Furnace AA (GFAA) spectroscopy. A mixture of nitric acid and sample was refluxed in a covered Griffin beaker. After the digestate has been brought to a low volume, it was cooled and brought up in dilute nitric acid $(3 \% \mathrm{v} / \mathrm{v})$. The sample was filtered, allowed settling and prepared it for analysis.

\subsection{Measurement of Enzyme Activity}

The activities of the selected enzymes were measured 
according to a modified protocol based on $[25,43]$. Liver and muscles samples of 24 African catfish collected from the selected sites were pulverized under liquid nitrogen and about $100 \mathrm{mg}$ of ground tissue powder was added to 5 vol. of buffer ( $50 \mathrm{mM}$ Tris, $\mathrm{pH} 7.4,1 \mathrm{mM}$ EDTA and $2 \mathrm{mM} \mathrm{MgCl2}$ ). Tissue was homogenized briefly with an Ultra-Turrax (temperature was maintained at $4{ }^{\circ} \mathrm{C}$ during homogenization). The homogenate was centrifuged for $15 \mathrm{~min}$ at $10,000 \mathrm{Xg}$ and $4^{\circ} \mathrm{C}$ and supernatants were used for the enzyme activity assays using spectrophotometer (Micro Lab 200 Vital Scientific, Dieren, The Netherlands) at a wavelength of $340 \mathrm{~nm}$ and at $37{ }^{\circ} \mathrm{C}$ using kits, Stanbio LDH (UV-Rate) procedure no. 0940 USA for the quantitative determination of lactate dehydrogenase and RANDOX Laboratories Ltd., PD410, UK BT294QY, for the quantitative determination of glucose-6-phosphate dehydrogenase [44]. The catalytic activities of the selected enzymes was calculated in accordance with the recommendations of the French Society of Clinical Biology and was expressed as $\mathrm{U} / \mathrm{g}$ tissues.

\subsection{Histological Investigations}

Liver and gills of 24 African catfish were collected from the selected sites. The organs were fixed in Bouin's solution, dehydrated, embedded in paraffin wax and sectioned at 4-7 $\mu \mathrm{m}$. Slides were stained with haematoxylin and eosin and examined microscopically [45].

\subsection{Statistical Analysis}

All values from chemical analyses and enzyme activities are presented as mean $\pm \mathrm{SD}$. Data obtained from the experiment were subjected to one way analysis of variance (ANOVA) test using the Statistical Package for the Social Sciences [46].

\section{RESULTS}

\subsection{Water Analysis}

The results of means and SD of the studied physical and chemical parameters for water samples are given in Table 1. According to the present results the $\mathrm{pH}$ seems to be constant all over the river Nile. All the $\mathrm{pH}$ values were in alkaline side ( 7.8 to 8.4 ). Electrical conductivity showed lowest values at Aswan $(0.257 \mathrm{mScm}-1)$ and the highest value were recorded at Rosetta $(0,576 \mathrm{mScm}-1)$ followed by Damietta $(0.379 \mathrm{mScm}-1)$ with a significant $(\mathrm{p}<0.05)$ increase from Aswan to Damietta and then Rosetta branch (Table 1). Chemical oxygen demand (COD) and Total organic compound (TOC) were significantly $(p<0.05$ ) higher in the water of Rosetta branch comparing to the other sites. The lowest values of such parameters were detected in the Aswan and Qena
(Table 1). The value of COD in Rosetta branch, Assiut and Aswan was higher than the permissible limits. The highest concentration of the total solid (TS) was detected in the water of Rosetta followed by Damietta branch. The lowest value of TS was recorded in the water of Aswan followed by Qena (Table 1). The concentration of ammonia and nitrate were lower than the permissible limits along the whole course of the river Nile but they still higher in the water of Rosetta and Damietta branch comparing to Aswan site (Table 1). The value of fluoride was higher in Assuit and Rosetta branch than other sites (Table 1). The level of Cholride and Sulphate exhibited higher values in the water of Rosetta and Damietta branches comparing to other sites (Table 1). The level of Orthophosphate in the Rosetta branch was higher than other sites (Table 1). The concentration of phenolics was higher than the permissible limits in Rosetta and Damietta branches (Table 1). The values of the selected metals in the water of the River Nile were lower than the permissible limits nearly in all sites (Table 1). The lead and chromium concentrations were higher than the permissible limit in the Rosetta branch. The cadmium and mercury levels were higher than the permissible limits in Rosetta and Damietta branches (Table 1).

\subsection{Metabolic Enzyme Activities}

The results of the two metabolic enzymes (G6PDH and LDH) in the liver and muscles of the African catfish Clarias gariepinus collected from the selected sites are presented in Table (2). The activities of G6PDH and $\mathrm{LDH}$ in the muscles were always higher than that in the liver of fish collected from the same site (Table 2). The activity of G6PDH in the liver and muscles tissues of the African catfish decreased significantly $(\mathrm{p}<0.05)$ from Aswan to Damietta and Rosetta branch (Table 2). The highest G6PDH activity was recorded in the tissues of fish collected from Aswan comparing to other sites (Table 2). On the other hand the lowest G6PDH activity was recorded in the tissues of the African catfish collected from Rosetta (Table 2).

The activity of Lactate Dehydrogenase (LDH) in the muscles and liver of African catfish increased significantly $(\mathrm{p}<0.05)$ from Aswan toward Rosetta and Damietta branches (Table 2). The lowest LDH activity was recorded in the tissues of fish collected from Aswan (Table 2). The highest value of LDH activity was in liver of fish collected from Damietta $(1388.5 \mathrm{U} / \mathrm{g})$ and in the muscles of fish collected from Rosetta $(1529.2 \mathrm{U} / \mathrm{g})$ (Table 2). The activity of LDH in the muscles of the African catfish seemed to be constant between Aswan and Qena (Table 2). 
Table 1. Physical and chemical parameters of the water collected from different sites along the whole course of the river Nile, Egypt.

\begin{tabular}{|c|c|c|c|c|c|c|c|}
\hline Sites & Aswan & Qena & Assiut & Beny-Suef & Damietta & Rosetta & \multirow{2}{*}{$\begin{array}{c}\text { Permissible } \\
\text { limit }\end{array}$} \\
\hline$\underline{\text { Parameter (unit) }}$ & Mean \pm SD & Mean $\pm \mathrm{SD}$ & Mean \pm SD & Mean $\pm \mathrm{SD}$ & Mean $\pm \mathrm{SD}$ & Mean $\pm \mathrm{SD}$ & \\
\hline PH (Unit) & $7.858 \pm 0.248$ & $8.009 \pm 0.405$ & $8.152 \pm 0.187$ & $8.27 \pm 0.273$ & $8.402 \pm 0.442$ & $8.225 \pm 0.449$ & $7-8.5$ \\
\hline Conductivity ( $\mathrm{Ms} / \mathrm{cm})$ & $0.257 \pm 0.029$ & $0.270 \pm 0.0701$ & $0.285 \pm 0.086$ & $0.336 \pm 0.0722$ & $0.379 \pm 0.099$ & $0.576 \pm 0.115$ & - \\
\hline Temperature $\left({ }^{\circ} \mathrm{C}\right)$ & $22.683 \pm 2.218$ & $23.7167 \pm 3.152$ & $23.33 \pm 4.671$ & $23.644 \pm 4.239$ & $25.292 \pm 5.661$ & $24.525 \pm 4.441$ & Over $5^{\circ} \mathrm{C}$ \\
\hline $\begin{array}{c}\text { Chemical oxygen } \\
\text { demand (ppm) }\end{array}$ & $10.583 \pm 3.616$ & $9.167 \pm 3.0419$ & $10.63 \pm 2.179$ & $7.875 \pm 2.153$ & $8.592 \pm 2.509$ & $18 \pm 10.375$ & 10 \\
\hline $\begin{array}{l}\text { Total organic carbon } \\
(\mathrm{ppm})\end{array}$ & $5.651 \pm 2.876$ & $5.893 \pm 1.925$ & $5.738 \pm 0.918$ & $4.93 \pm 2.575$ & $5.209 \pm 2.635$ & $8.61 \pm 6.055$ & - \\
\hline Total solid (ppm) & $198.875 \pm 14.088$ & $212.667 \pm 23.70$ & $227.75 \pm 16.297$ & $259.5 \pm 44.33$ & $305.25 \pm 55.95$ & $411.25 \pm 85.66$ & 500 \\
\hline Ammonia (ppm) & $0.1058 \pm 0.158$ & $0.0086 \pm 0.0014$ & $0.0198 \pm 0.011$ & $0.0125 \pm 0.0098$ & $0.0447 \pm 0.048$ & $0.146 \pm 0.091$ & 0.5 \\
\hline Nitrate (ppm) & $0.8084 \pm 0.396$ & $0.765 \pm 0.3868$ & $0.506 \pm 0.205$ & $0.7233 \pm 0.627$ & $1.1341 \pm 1.131$ & $2.049 \pm 2.271$ & 45 \\
\hline Chlorides (ppm) & $7.0524 \pm 1.443$ & $8.56 \pm 1.896$ & $10.032 \pm 2.58$ & $15.28 \pm 5.103$ & $22.4199 \pm 4.92$ & $40.546 \pm 6.722$ & - \\
\hline Florid (ppm) & $0.2836 \pm 0.146$ & $0.319 \pm 0.1383$ & $0.388 \pm 0.163$ & $0.314 \pm 0.125$ & $0.301 \pm 0.0971$ & $0.372 \pm 0.0737$ & 0.5 \\
\hline $\begin{array}{l}\text { Ortho phosphate } \\
\text { (ppm) }\end{array}$ & $0.014 \pm 0.0198$ & $0.0367 \pm 0.0381$ & $0.0937 \pm 0.090$ & $0.0334 \pm 0.034$ & $0.132 \pm 0.066$ & $0.211 \pm 0.1871$ & - \\
\hline Sulphate (ppm) & $34.167 \pm 13.299$ & $45.33 \pm 15.37$ & $47.957 \pm 14.11$ & $45.25 \pm 15.81$ & $51 \pm 12.759$ & $68.125 \pm 11.42$ & 200 \\
\hline Phenol (ppm) & $0.0234 \pm 0.0227$ & $0.0213 \pm 0.0198$ & $0.016 \pm 0.0157$ & $0.0155 \pm 0.0098$ & $0.0287 \pm 0.017$ & $0.0401 \pm 0.022$ & 0.02 \\
\hline $\mathrm{Pb}(\mathrm{ppm})$ & $0.0177 \pm 0.015$ & $0.02128 \pm 0.014$ & $0.0248 \pm 0.0174$ & $0.01618 \pm 0.009$ & $0.0335 \pm 0.04$ & $0.0562 \pm 0.078$ & 0.05 \\
\hline $\mathrm{Cd}(\mathrm{ppm})$ & $0.00379 \pm 0.004$ & $0.002124 \pm 0.00$ & $0.00644 \pm 0.007$ & $0.00236 \pm 0.002$ & $0.01586 \pm 0.02$ & $0.0124 \pm 0.017$ & 0.1 \\
\hline $\mathrm{Zn}(\mathrm{ppm})$ & $0.2107 \pm 0.173$ & $0.1237 \pm 0.101$ & $0.3091 \pm 0.46$ & $0.33659 \pm 0.45$ & $0.45057 \pm 0.68$ & $0.695 \pm 0.955$ & 1 \\
\hline $\mathrm{Cu}(\mathrm{ppm})$ & $0.0305 \pm 0.027$ & $0.0274 \pm 0.024$ & $0.03022 \pm 0.026$ & $0.03197 \pm 0.027$ & $0.03206 \pm 0.03$ & $0.0544 \pm 0.027$ & 1 \\
\hline $\mathrm{Cr}(\mathrm{ppm})$ & $0.00352 \pm 0.002$ & $0.00653 \pm 0.005$ & $0.00558 \pm 0.005$ & $0.0060359 \pm 0.005$ & $0.04548 \pm 0.06$ & $0.088 \pm 0.154$ & 0.05 \\
\hline $\mathrm{Fe}(\mathrm{ppm})$ & $0.197 \pm 0.1762$ & $0.2205 \pm 0.195$ & $0.3449 \pm 0.32$ & $0.45957 \pm 0.39$ & $0.40742 \pm 0.27$ & $0.4973 \pm 0.44$ & 1 \\
\hline $\mathrm{Hg}(\mathrm{ppm})$ & $0.00099 \pm 0.001$ & $0.00041 \pm 0.000$ & $0.00053 \pm 0.001$ & $0.00096 \pm 0.0009$ & $0.0021 \pm 0.001$ & $0.0034 \pm 0.001$ & 0.001 \\
\hline $\mathrm{Mn}(\mathrm{ppm})$ & $0.03319 \pm 0.02771$ & $0.0651 \pm 0.0685$ & $0.04511 \pm 0.0216$ & $0.0589 \pm 0.06058$ & $0.071 \pm 0.0851$ & $0.0996 \pm 0.146654$ & 0.5 \\
\hline
\end{tabular}

Table 2. Activities of Glucose-6-Phosphate Dehydrogenase (G6PDH) Lactate Dehydrogenase (LDH) in the liver and muscles of the African catfish Clarias gariepinus collected from different sites along the whole course of the river Nile, Egypt.

\begin{tabular}{|c|c|c|c|c|}
\hline \multirow[t]{2}{*}{ Sites } & \multicolumn{2}{|c|}{ G6PDH (U/g) } & \multicolumn{2}{|c|}{ LDH $(\mathrm{U} / \mathrm{g})$} \\
\hline & Liver & Muscles & Liver & Muscles \\
\hline Aswan & $71.6 \pm 2.4$ & $71.9 \pm 0.96$ & $1191.7 \pm 95.91$ & $1389.8 \pm 11.4$ \\
\hline Qena & $60.7 \pm 1.3$ & $71.9 \pm 0.97$ & $1199.4 \pm 51.25$ & $1389.4 \pm 2.5$ \\
\hline Assiut & $55.8 \pm 2.2$ & $66.7 \pm 2.34$ & $1245.6 \pm 106 . .7$ & $1416.3 \pm 4.7$ \\
\hline Beny-Suef & $57.2 \pm 0.8$ & $61.4 \pm 0.95$ & $1340.7 \pm 1.29^{*}$ & $1431.0 \pm 59.5^{*}$ \\
\hline Damietta & $46.9 \pm 8.8^{*}$ & $51.0 \pm 11.00^{*}$ & $1388.5 \pm 7.15^{*}$ & $1513.7 \pm 4.6^{*}$ \\
\hline Rosetta & $46.7 \pm 1.2^{*}$ & $49.7 \pm 2.38^{*}$ & $1378.7 \pm 6.85^{*}$ & $1529.2 \pm 52.7^{*}$ \\
\hline
\end{tabular}

Results are expressed as means \pm SD. Significant comparing to Aswan site at 0.05 levels.

\subsection{Histopathology}

Remarkable structural changes were detected in the tissues of the African catfish collected from the whole course of the rive Nile. Significant differences in the degree of such changes were recorded according to the degree of pollution in the site. Figure 2 (a,b) shows the normal histological structure of the liver. The photomi- 
crograph of the normal liver shows the parenchyma cells (C) arranged to form a lattice network. The interspaces are the sinusoid (S) of thin strip with sparse connective tissue. The sinusoids made continuous communication as they were seen converging into the central vein $(\mathrm{V})$. Also the hepatopancrease (hp) was clearly distinguished between the liver tissues (Figure 2(b)). The histopathological changes found in the liver of the examined fish included irregular arrangements of hepatocytes, vacuolation (va) and necrosis (ne) of the cytoplasm (Figure 2(c)). In the fishes collected from Damietta and Rosetta, patchy degeneration and isolated degenerated elements around the parenchyma cells were observed with progressive increase of fibro-connective tissue (fct) (Figure 2(d)). Leukocyte infiltration (inf) and hemorrhage (hem) were also detected in the hepatic tissues of some fish (Figure 3(a,b)). Also, acute and extensive vacuolization (vac) and necrosis (nec) of liver cells was observed (Figure 3(c)) in the liver of fish collected from Damietta and Rosetta branches. Dilation of the central vein accompanied by blood congestion (bc) (Figure 3(d)) was detected.

Light microscopic examination of photomicrograph of the normal gills (Figure 4(a)) shows the arrangement of the lamella. In the core was a cartilaginous supporting rod and blood vessels with traces of sinusoidal blood spaces. The primary lamella $(\mathrm{P})$ was rounded at the apices while the projecting secondary lamellas (S) were clearly interspaced. The histological alteration of the gill of fish collected from the river Nile included primary and secondary lamella overlapping (Figure 4(b)). Thus there was occlusion of inter lamella spaces. The core

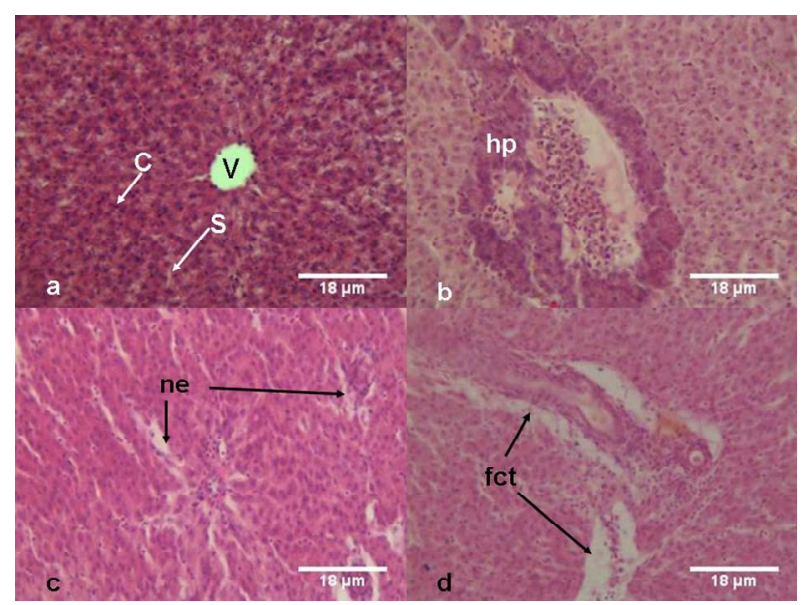

Figure 2. Photomicrograph of liver tissue showing a, b) normal liver of Clarias gariepinus collected from Aswan, c, d) histopatholoical changes in the liver of Clarias gariepinus collected from Damietta and Rosetta branch. Stained with H\&E. (C) parenchyma Cells (S) Sinusoid (V) central Vein (hp) hepatopancreas (ne) necrosis (fct) fibro-connective tissues apparent.

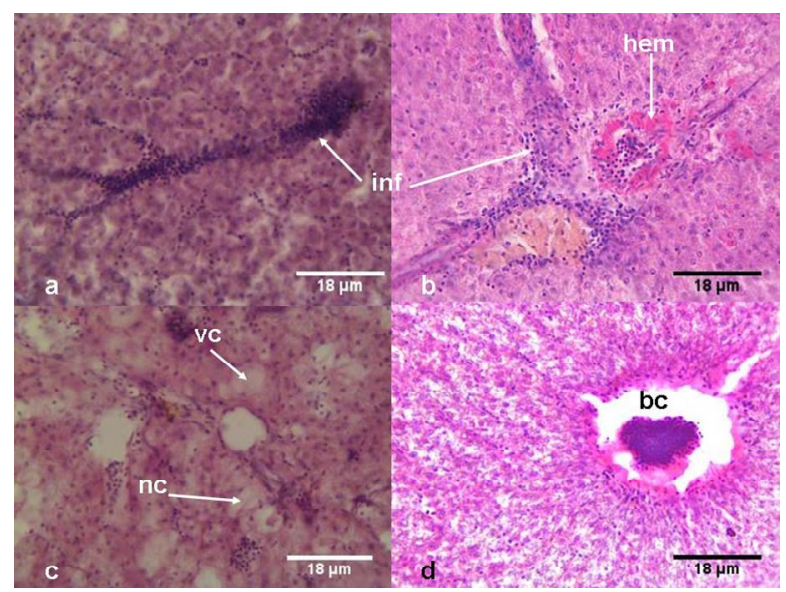

Figure 3. Photomicrograph of liver tissue showing deformities in the tissue of Clarias gariepinus collected from Damietta and Rosetta a, b) liver tissues with leucocytes infiltration and haemorrhage, c) liver tissues with extensive vacuolization and necrosis, d) showing dilation of the central vein with blood congestion. Stained with H\&E. (inf) infiltration, (hem) haemorrhage, (va) vacuolization, (bc) blood congestion.
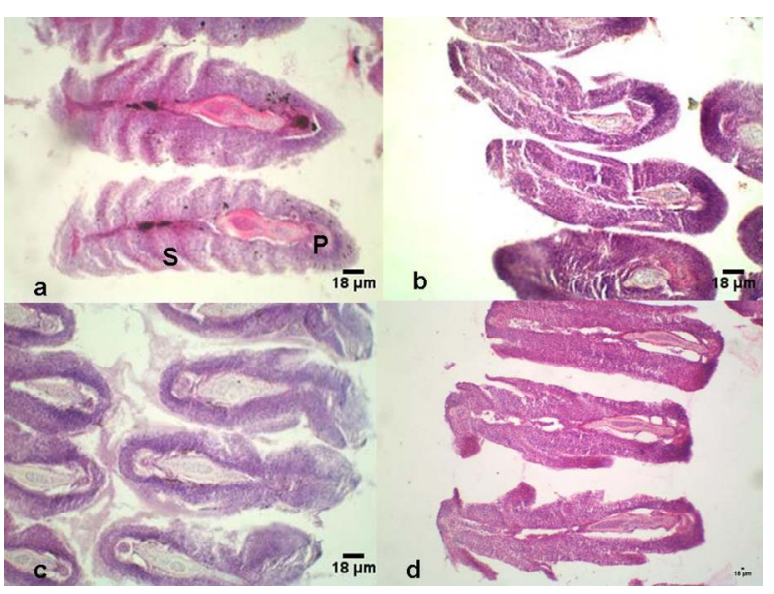

Figure 4. Photomicrograph of gills of Clarias gariepinus showing a) normal gills of the fishes collected from Aswan with regular arrangement of the Primary $(\mathrm{P})$ and Secondary (S) lamella, b) histological alteration of the gill showing primary and secondary lamella overlapping, c) shrinkage of cartilaginous supporting mass, d) showing lysis in the epithelium cells. Stained with H\&E.

was thin and indistinct. There was shrinkage of cartilaginous supporting mass resulting in decrease in size of the gills (Figure 4(c)). At Rosetta and Damietta, the epithelium was disrupted owing to the lysis of the cells (Figure 4(d)). Sever degeneration and necrotic changes in gill filaments were recorded (Figure 5(a,b)). The increase in intracellular vacuolation (Figure 5(c)) signals onset of oedematous changes. Frequently, alterations such as dilation and congestion in blood vessel of gill filaments were detected (Figure 5(d)). The gills show further shrinkage making the cartilaginous core absolutely 


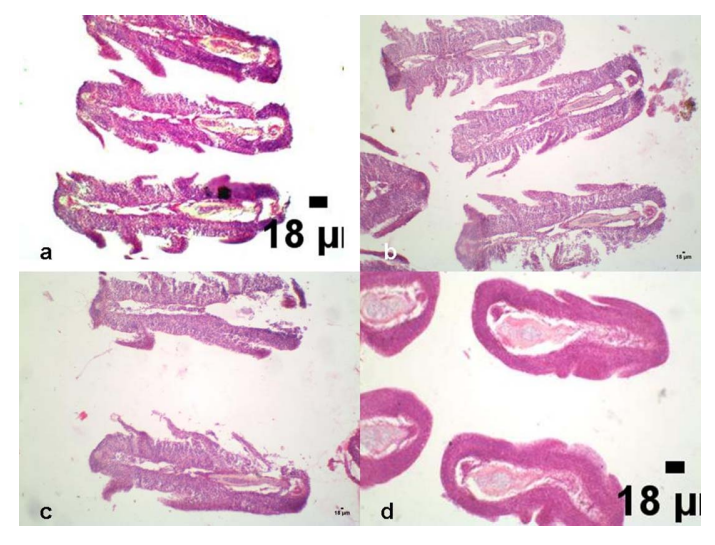

Figure 5. Photomicrograph of gills of Clarias gariepinus shows the deformation a, b) Severe degeneration and necrotic changes in gill filaments, c) intracellular vacuolation and edema, d) dilation and congestion in blood vessel of gill filaments. Stained with H\&E.

obscured. Table 3 show the distribution of the detected lesions in the liver and gills of the African catfish. From such table we concluded that all of the detected histopathological lesions were recorded in the tissues of the African catfish collected from Rosetta and Damietta branches. Some of them were recorded in the tissues of fish collected from other sites (Table 3).

\section{DISCUSSIONS}

According to the results of the present work most of the detected physical and chemical parameters were significantly higher in the water collected from Rosetta and Damietta branches comparing to other sites. The values of the selected metals in the water of the river Nile were less than the permissible limits nearly in all sites but they still higher in the water of Rosetta and Damietta comparing to other sites. Lead, cadmium, chromium and mercury concentrations were higher than the permissible limit in the water collected from Rosetta and Damietta branches. Such results prove the presence of large quantities of organic and inorganic pollutants and disposal of domestic and industrial effluent in the water of Rosetta and Damietta branch. This was expected due to the fact that the water of such branches receives large quantities of domestic, agricultural and industrial effluents without sufficient treatments.

The alteration in enzyme activity has been advocated to provide an early warning of potentially damaging changes in stressed fish [25]. The altered activities of G6PDH and LDH could be useful biomarkers of water pollution [25]. The results of the present work recorded a remarkable alteration in the activity of the selected en-

Table 3. Distribution of the detected histopathological lesions in the tissues of the African catfish Clarias gariepinus collected from different sites along the whole course of the river Nile, Egypt.

\begin{tabular}{|c|c|c|c|c|c|c|c|}
\hline Organ & Histopathological changes & Aswan & Qena & Assiut & $\begin{array}{l}\text { Beny } \\
\text { Suef }\end{array}$ & Damietta & Rosetta \\
\hline & Irregular arrangements of hepatocytes & + & + & + & + & + & + \\
\hline & Vacuolation & + & + & + & + & + & + \\
\hline & Necrosis & + & + & + & + & + & + \\
\hline \multirow[t]{5}{*}{ Liver } & $\begin{array}{l}\text { Degeneration and increase of } \\
\text { fibro-connective tissue }\end{array}$ & & & & & + & + \\
\hline & Leukocyte infiltration & & & & & + & + \\
\hline & $\begin{array}{c}\text { Dilation of the central vein with blood } \\
\text { congestion }\end{array}$ & & & & & + & + \\
\hline & $\begin{array}{c}\text { Primary and secondary lamella overlap- } \\
\text { ping }\end{array}$ & + & + & + & + & + & + \\
\hline & Shrinkage of cartilaginous supporting & + & + & + & + & + & + \\
\hline \multirow[t]{3}{*}{ Gill } & Cell lysis & & & & & + & + \\
\hline & $\begin{array}{l}\text { Sever degeneration and necrotic changes } \\
\text { in gill filaments }\end{array}$ & & & & & + & + \\
\hline & Oedematous changes & & & & & + & + \\
\hline
\end{tabular}

zymes in the tissues of African catfish. These alterations goes in parallel with the elevation in the levels of water chemical parameters detected in the water of Damietta and Rosetta branches as a result of pollution stress in these areas. These overall changes in the metabolic key enzymes in the tissues of fishes collected from Rosetta and Damietta branches indicate that major changes occur in carbohydrate and protein metabolism. Glutathione
(GSH) serves to protect the cell against oxidative damage as it conjugates with compounds of exogenous and endogenous origin [47]. GSH production requires NADPH to be synthesized in the pentose phosphate metabolic pathway in which G6PD participate. For this reason, G6PD is considered as antioxidant enzymes [26]. The activity of G6PDH was significantly decreased from Aswan to Rosetta and Damietta recording the lowest 
value at Rosetta followed by Damietta water. Such reduction in G6PDH activity in the liver and muscles of the African catfish was also previously observed in some fishes exposed to toxicants $[48,49]$. Thus the observed decrease in activity of G6PDH in the present work may reflect metabolic imbalance after pollution stress in direct relation to the limited availability of NADPH.

LDH is an important factor in the ability of some fish to produce sudden bursts of swimming and is found in large quantities in red muscle when a metabolic investment in locomotion capacity makes good adaptation sense [50]. Anaerobic capacity was estimated by the activity of lactate dehydrogenase (LDH), the terminal enzyme of anaerobic glycolysis located in the cellular cytoplasm. This enzyme commonly reflects the metabolic capacity of tissues after long - term exposure to contaminated water bodies $[51,52]$. LDH catalyses the conversion of pyruvic acid to lactic acid under stressed conditions. The activity of LDH, which is a cytoplasmic enzyme, showed a marked elevation in the tissues of fishes collected from Rosetta and Damietta branches comparing to other sites. LDH activity is generally associated with cellular metabolic activity which acts as a pivotal enzyme between the glycolytic pathway and the tricarboxylic acid cycle [53]. Thus, elevation of LDH may suggest a bias towards the anaerobic glycolytic pathway. By other meaning, changes in the lactate dehydrogenase activity may indicate the facility with which the African catfish can shift to anaerobic metabolism under stressed conditions. Liver is one of the richest sources of LDH and the leakage of enzyme from even small mass of damaged liver tissue can increase the observed level to a significant extent. The increase in the activity of enzymes after exposure to some pollutants was explained as a result of destruction of liver cells and increased cell permeability leading to a leakage of the enzymes from the damaged liver cells into the serum $[28,54,55]$.

These alterations in enzymatic activities were confirmed, in the present study by determination histopathological alterations and clear damage of liver cells of the African catfish which collected from the same sites of the Rive Nile. The results of the present work manifest histopathological changes in the liver and gills of the African catfish collected from different localities along the whole course of the river Nile. Histopathological biomarkers of toxicity in fish organs are a useful indicator of environmental pollution [56]. In fact, the histological studies are considered as direct indication of any adverse effect on fish. Numbers of histological lesions have been detected in the tissues of the African catfish. Liver of the African catfish showed degeneration in the hepatocytes, necrosis and aggregation of inflammatory cells, dilatation and congestion in blood sinusoid and fibrosis. These changes may be attributed to the direct toxic effects of pollutants on hepatocytes, since the liver is the principal organ responsible for detoxification in vertebrates generally and in fish particularly. One of the most important functions of liver is to clean pollutants from the blood coming from the intestine, so it is considered as indicator of aquatic environmental pollution [57]. The vacuolization of hepatocytes might indicate an imbalance between the rate of synthesis of substances in the parenchyma cells and the rate of their release into the circulation [58]. The present results are in agreement with those observed by many authors who studied the effects of different pollutants on fish liver [59-61].

Gills remain in close contact with the external environment and particularly sensitive to change in the quality of water are considered the primary target organ of the contaminant [62]. The cellular damages observed in the gills in term of epithelium proliferation and necrosis can adversely affect the gas exchange and ionic regulation [62]. The observed edematous changes in gill filaments probably due to increased capillary permeability [61]. Alterations like fusion of some secondary lamellae are examples of defense mechanisms, since; in general, these result in the increase of the distance between the external environment and the blood and thus serve as a barrier to the entrance of contaminants $[63,64]$. Similar lesions have been previously reported by some authors in some fish species exposed to different kind of pollution $[65,66]$ Rosety-RodrÃ-guez, $2002 \# 2696\}[60,63,67,68]$. This means, such alterations are non-specific and may be induced by different types of contaminants As a consequence of the increased distance between water and blood due to epithelial lifting, the oxygen uptake is impaired. However, fishes have the capacity to increase their ventilation rate, to compensate low oxygen uptake [69]. According the results of the present work altered metabolic enzymes activities can provide a tool to assess the geographical areas impacted by aquatic pollutions. The altered activities of G6PDH and LDH can provide a useful biomarker for fish farms and for environmental managers in investigating the exposure of fish to contaminated waters. All of the above mentioned histopathological lesions were recorded in the tissues of fish collected from Rosetta and Damietta branches. Some of them were recorded in the tissues of fish collected from other sites. So, histopathology provides a reliable, easily quantifiable index of low-level toxic stress to a broad range of environmental pollutants. It is possible that the enzymatic and pathological alterations in the selected tissues could be a direct result of the industrial, agricultural, domestic waste products which are entered to the Nile with the drainage water. 


\section{ACKNOWLEDGEMENTS}

This work was supported by Science and Technology development fund (Project ID 448).

\section{REFERENCES}

[1] Canli, M. and Kalay, A. (1998) Level of heavy metals $(\mathrm{Cd}, \mathrm{Pb}, \mathrm{Cu}, \mathrm{Cr}$ and $\mathrm{Ni})$ in tissue of Cyprinus carpio, Barbus capito and Chondrostoma regium from the Seyhan River, Turkey. Turkish journal of zoology, 22, 149-157.

[2] Vutkuru, S. (2005) Acute effects of Hexavalent chromium on survival, oxygen consumption, Hematological parameters and some biochemical profiles of the Indian Major Carp, Labeo rohita. International Journal of Environmental Research and Public Health, 2, 456-462.

[3] Anwar, W.A. (2003) Environmental health in Egypt. International journal of hygiene and environmental health, 206, 339-350.

[4] Osman, A.G.M., Al-Awadhi, R.M., Harabawy, A.S. and Mahmoud, U.M. (2010) Evaluation of the Use of Protein Electrophoresis of the African Catfish Clarias gariepinus (Burchell, 1822) for Biomonitoring Aquatic Pollution. Environmental Research Journal, 4, 235-243.

[5] Abdel-Satar, A. (1998) Distribution of some chemical elements in River Nileenvironments at Great Cairo Region. Faculty of Science, Cairo University. Egypt.

[6] Abdel-Satar, A. and Elewa, A. (2001) Water quality and environmental assessments of the River Nile at Rossetta Branch. The Second International Conference and Exhibition for Life and Environment, Aswan, 2001, 136-164.

[7] Elewa, A. and Gohar, M. (1999) Environmental factors affecting the precipitation and dissolution of $\mathrm{Fe}, \mathrm{Mn}, \mathrm{Zn}$, $\mathrm{Cu}, \mathrm{Pb}$ and $\mathrm{Cd}$ in River Nile at Damietta Branch. Bulleten of Faculty of Science. Zagazig University, 21, 114-136.

[8] Zyadah, M. and Chouikhi, A. (1999) Heavy metal accumulation in Mullus barbatus, Merluccius merluccius and Boops boops fish from the Aegean Sea, Turkey. International journal of food sciences and nutrition, 50, 429-34.

[9] Rashed, M. (2001) Monitoring of environmental heavy metals in fish from Nasser Lake. Environment International, 27, 27-33.

[10] Rashed, M. (2001) Cadmium and lead levels in fish (Tilapia nilotica) tissues as biological indicator for lake water pollution. Environmental Monitoring and Assessment, 68, 75-89.

[11] Adham, K. (2002) Sublethal effects of aquatic pollution in Lake Maryut on the African sharptooth catfish, Clarias gariepinus (Burchell, 1822). Journal of Applied Ichthyology, 18, 87-94.

[12] Abdo, M. (2004) Environmental studies on the River Nile at Damietta Branch region, Egypt. Journal of Egyptian Society of Environmental Development Studies, 5, 85-104.
[13] Wahaab, R.A. and Badawy, M.I. (2004) Water quality assessment of the River Nile system: An overview. Biomedical and environmental sciences: BES, 17, 87100.

[14] El-Shaikh, K., Nadam, A. and Zousief, Z. (2005) Assessment of cadmium and lead in water, sediment and different organs of Procambarus clarkii (GIRARD, 1852) in the river Nile. Medical Journal of Islamic World Academy of Sciences 4, 15, 161-167.

[15] Abdel-Halim, K.Y., Salama, A.K., El-Khateeb, E.N. and Bakry, N.M. (2006) Organophosphorus pollutants (OPP) in aquatic environment at Damietta Governorate, Egypt: implications for monitoring and biomarker responses. Chemosphere, 63, 1491-1498.

[16] Badr, M., Elewa, A., Shehata, M., Mohamed, L. and Abdelaziz, G. (2006) Studies on the effect of Elrahawy drain on the river Nile water pollution by trace metals and major cation at Elkanater ElKyria area under the effect of seasonal variation. Assiut University Bulleten of Environmental Research, 9, 35-54.

[17] Rifaat, H. (2007) Bacterial Quality of River Nile Water at Cairo Region in Egypt. Helsinki, 59, 1-8.

[18] Goksoyr, A., Husoy, A., Larsen, H., Klungsoyr, J., Wilhelmsen, S., Maage, A., Brevik, E., Andersson, T., Celander, M., Pesonen, M., et al. (1991) Environmental contaminants and biochemical responses in flatfish from the Hvaler Archipelago in Norway," Archives of Environmental Contamination and Toxicology, 21, 486496.

[19] Kime, D., Ebrahimi, M., Nysten, K., Roelants, I., Rurangwa, E., Moore, H. and Ollevier, F. (1996) Use of computer assisted sperm analysis (CASA) for monitoring the effects of pollution on sperm quality of fish; Application to the effects of heavy metals. Aquatic Toxicology, 36, 223-237.

[20] Jiminez, B. and Stegeman, J. (1990) Detoxification enzymes as indicator of environmental stress on fishes. American Fish Society Symposium, 8, 69-79.

[21] Barnhoorn, I. (1996) Effects of manganese on the haematology of the Oreochromis mossambicus and the bioaccumulation of metals in Labeo umbratus. Rand Afrikaans University, South Africa, 1996.

[22] Powers, D. (1989) Fish as model systems. Science, 246, 352-358.

[23] Gayet, J., Haouz, A., Gelosomeyer, A. and Burstein, C. (1993) Detection of heavy-metal salts with biosensors built with an oxygen-electrode coupled to various immobilized oxidases and dehydrogenases. Biosensors and Bioelectronics, 8, 177-183.

[24] Zollner, H. (1993) Handbook of enzyme inhibitors. New York FG - 0: VCH, Weinheim, Basel, New York.

[25] Osman, A.G.M., Mekkawy, I.A.A., Verreth, J. and Kirschbaum, F. (2007) Effects of lead nitrate on the activity of metabolic enzymes during early developmental stages of the African catfish Clarias gariepinus (Burchell, 1822). Fish Physiology and Biochemistry, 33, 1-13.

[26] Mekkawy, I.A.A., Mahmoud, U.M., Osman, A.G. and Sayed, A.E.-D.H. (2009) Effects of ultraviolet A on the activity of two metabolic enzymes, DNA damage and lipid peroxidation during early developmental stages of 
the African catfish, Clarias gariepinus (Burchell, 1822). Fish physiology and biochemistry, 36, 605-626.

[27] Casillas, E., Myers, M. and Ames, W. (1983) Relationship of serum chemistry values to liver and kidney histopathology in english sole (Parophrys vetulus) after acute exposure to carbon-Tetrachloride. Aquatic Toxicology, 3, 61-78.

[28] Heath, A. (1996) Water pollution and fish physiology. Lewis Publs., Boca Raton.

[29] Nogae, I. and Johnston, M. (1990) Isolation and characterization of the Zwfl gene of Saccharomyces cerevisiae, encoding glucose-6-phosphate-dehydrogenase. Gene, 96, 161-169.

[30] Pandolfi, P., Sonati, F., Rivi, R., Mason, P., Grosveld, F. and Luzzatto, L. (1995) Targeted disruption of the housekeeping gene encoding glucose-6-phosphatedehydrogenase (G6pd)-G6pd is dispensable for pentose synthesis but essential for defense against oxidative stress. Embo Journal, 14, 5209-5215.

[31] Salvemini, F., Franze, A., Iervolino, A., Filosa, S., Salzano, S. and Ursini, M. (1999) Enhanced glutathione levels and oxidoresistance mediated by increased glucose-6-phosphate dehydrogenase expression. Journal of Biological Chemistry, 274, 2750-2757.

[32] Ramesh, M., Sivakumari, K. and Kanagaraj, M. (1993) Toxicity of dye effluent in lactate dehydrogenase activity in Labeo rohita. Journal of environmental Prot. 13, 124-127.

[33] Das, P., Ayyappan, S., Das, B. and Jena, J. (2004) Nitrite toxicity in Indian major carps: sublethal effect on selected enzymes in fingerlings of Catla catla, Labeo rohita and Cirrhinus mrigala. Comparative Biochemistry and Physiology C-Toxicology \& Pharmacology, 138, 310.

[34] Das, P., Ayyappan, S., Jena, J. and Das, B. (2004) Acute toxicity of ammonia and its sub-lethal effects on selected haematological and enzymatic parameters of mrigal, Cirrhinus mrigala (Hamilton). Aquaculture Research, 35, 134-143.

[35] Shaklee, J., Champion, M. and Whitt, G. (1974) Developmental genetics of teleosts-biochemical analysis of lake Chubsucker ontogeny. Developmental Biology, 38, 356-382.

[36] Meyers, M., Johnson, L., Hom, T., Collien, T., Stein, J., Varanasi, U. and Washington, U. (1998) Toxipathic Hepatic lesion in subadult English Sole (Pleurinectes vetulus) from Puget sound, Relationship with other Biomarkers of contaminant Exposure. Marine Enviromental Research, 45, 47-67.

[37] Sing, R. and Sharm, B. (1998) Cr bofuran-induced biochemical changes in Clarias batrachus. Journal of Pest Science, 53, 285-290.

[38] Long, S., Ryder, K. and Holdway, D. (2003) The use of respiratory enzymes as biomarkers of petroleum hydrocarbon exposure in Mytilus edulis planulatus. Ecotoxicology and Environmental Safety, 55, 261-270.

[39] Klontz, G. (1985) Diagnostic methods in fish diseases: Present status and needs. In: Ellis, A.E. Ed., Fish and Shellfish Pathology, European Association of Fish Pathology. Academic Press, London, England, 3-9.
[40] Ferguson, H. (1989) Systemic pathology of fish: and atlas of comparative tissue responses in diseases of teleosts. Iowa State University Press, Ames, Iowa.

[41] Moeller, H. (1985) A critical review on the role of pollution as a cause of fish diseases. In: Ellis, A.E. Ed., Fish and Shellfish Pathology, European Association of Fish Pathology. Academic Press, London, England, 169-182.

[42] APHA, (2005) Standard methods for the examination of water \& wastewater. Amer Public Health Assn.

[43] Hardewig, I., Portner, H. and van Dijk, P. (2004) How does the cold stenothermal gadoid Lota lota survive high water temperatures during summer? Journal of Comparative Physiology B-Biochemical Systemic and Environmental Physiology, 174, 149-156.

[44] Kachmar, J. and Moss, D. (1976) Fundamentals of clinical chemistry. 2nd Edition, Philadelphia FG - 0: WB Saunders.

[45] Osman, A.G.M., Wuertz, S., Mekkawy, I.A.A., Verreth, J. and Kirschbaum, F. (2008) Early development of the African catfish Clarias gariepinus (Burchell, 1822) focusing on the ontogeny of selected organs. Journal of Applied Ichthiology, 24, 187-195.

[46] SPSS, (1998) SPSS-Inc for Windows release. Chicago, 10.

[47] Singhal, R., Anderson, M. and Meister, A. (1987) Glutathione, a 1st Line of defense against cadmium toxicity. Faseb Journal, 1, 220-223.

[48] Bucher, F., Hofer, R., Krumschnabel, G. and Doblander, C. (1993) Disturbances in the prooxidant-antioxidant balances in the liver of bullhead (Cottus gobio) exposed to treated paper mill effluents. Chemosphere, 27, 13291338.

[49] Korsgaard, B. (2005) Metabolic changes associated with 17 alph-thinylestradiol exposure in the pregnant teleost Zoarces viviparus. Electric journal of ichthyology, 1, 10-20.

[50] Brightman, S. (1997) A localised oral health study based on the School Dental Inspection system, and its implications for the proposed national oral health database. Journal of the Irish Dental Association, 43, 2-6.

[51] Pelletier, D., Dutil, J., Blier, P. and Guderley, H. (1994) Relation between growth rate and metabolic organization of white muscle, liver and digestive-tract in Cod, Gadus morhua. Journal of Comparative Physiology B-Biochemical Systemic and Environmental Physiology, 164, 508.

[52] Gagnon, M.M. and Holdway, D.A. (1999) Metabolic enzyme activities in fish gills as biomarkers of exposure to petroleum hydrocarbons. Ecotoxicology and environmental safety, 44, 92-99.

[53] Chourpagar, A. and Kulkarni, G.K. (2009) Toxic Effect of Copper Sulphate on Lactate Dehydrogenase Activity in a Freshwater Crab, Barytelphusa cunicularis (Westwood). World Journal of Zoology, 4, 180-183.

[54] Wilkinson, J. (1976) The principles and practice of diagnostic enzymology. Fundamentals of clinical chemistry, 30, 379-385.

[55] Elezabi, M.M., El serafy, S., Hechnann, R., Sharaf Eldeen, K.H. and Seddek, M.N. (2001) Effects of some toxicants on the freshwater fish, Oreochromis niloticus. 
Journal of Egyptian. German. Society Zoology, 36, 47-343.

[56] Peebua, P., Kruatrachue, M., Pokethitiyook, P. and Singhakaew, S. (2008) Histopathological alterations of Nile tilapia, Oreochromis niloticus in acute and subchronic alachlor exposure. Journal of environmental biology / Academy of Environmental Biology, India, 29, 325-331.

[57] Soufy, H., Soliman, M., El-Manakhly, E. and Gaafa, A. (2007) Some biochemical and pathological investigations on monosex Tilapia following chronic exposure to carbofuran pesticides. Global Veterinaria, 1, 45-52.

[58] Gingerich, W. (1982) Hepatic Toxicology of Fishes. In: Weber, L.J. Ed., Aquatic Toxicology, Raven Press, New York, 55-105.

[59] Ptashynski, M.D., Pedlar, R.M., Evans, R.E., Baron, C.L. and Klaverkamp, J.F. (2002) Toxicology of dietary nickel in lake whitefish (Coregonus clupeaformis). Aquatic toxicology (Amsterdam, Netherlands), 58, 229247.

[60] Fanta, E., Rios, F.V.S.A., Rom££o, S., Vianna, A.C.C. and Freiberger, S. (2003) Histopathology of the fish Corydoras paleatus contaminated with sublethal levels of organophosphorus in water and food. Ecotoxicology and environmental safety, 54, 119-130.

[61] Olojo, E., Olurin, K., Mbaka, G. and Oluwemimo, A. (2005) Histopathology of the gill and liver tissues of the African catfish Clarias gariepinus exposed to lead. African Journal of Biotechnology, 4, 117-122.

[62] Mohamed, M., Osman, M., Potter, T. and Levin, R. (1998) Lead and cadmium in Nile River water and finished drinking water in greater Cairo, Egypt. Environment International, 24, 767-772.
[63] Camargo, M. and Martinez, C. (2006) Biochemical and physiological biomarkers in Prochilodus lineatus submitted to in situ tests in an urban stream in southern Brazil. Environmental Toxicology and Pharmacology, 21, 61-69.

[64] Camargo, M.M. and Martinez, C. (2007) Histopathology of gills, kidney and liver of a Neotropical fish caged in an urban stream. Neotropical Ichthyology, 5, 327-336.

[65] Oliveira, R.C.A., Pelletier, E., Pfeiffer, W.C. and Rouleau, C. (2000) Comparative uptake, bioaccumulation, and gill damages of inorganic mercury in tropical and nordic freshwater fish. Environmental Research, 83, 286-292.

[66] Cerqueira, C.C.C. and Fernandes, M.N. (2002) Gill tissue recovery after copper exposure and blood parameter responses in the tropical fish Prochilodus scrofa. Ecotoxicology and environmental safety, 52, 8391.

[67] Martinez, C.B.R., Nagae, M.Y., Zaia, C.T.B.V. and Zaia, D.A.M. (2004) Acute morphological and physiological effects of lead in the neotropical fish Prochilodus lineatus. Brazilian journal of biology $=$ Revista brasleira de biologia, 64, 797-807.

[68] Triebskorn, R., Telcean, I., Casper, H., Farkas, A., Sandu, C., Stan, G., Col'sfrescu, O., Dori, T. and Ki甲hler, H.-R. (2008) Monitoring pollution in River Mure إ Romania, part II: metal accumulation and histopathology in fish. Environmental monitoring and assessment, 141, 177188.

[69] Fernandes, M.N. and Mazon, A.F. (2003) Environmental pollution and fish gill morphology. In: Val, A.L. and Kapoor, B.G. Eds., Fish adaptaion, Science publisher, Enfield, 203-231. 